\title{
Memória e Cultura Escolar: a imagem fotográfica no estudo da escola primária de Curitiba ${ }^{1}$
}

\section{School Memory and Culture: the photographic image in survey of primary school from Curitiba.}

Marcus Levy BENCOSTTA*

\begin{abstract}
Resumo: Este artigo pretende refletir algumas questões acerca do uso da fotografia na investigação histórica a partir da experiência de pesquisa que tem utilizado esta documentação como principal fonte de explicações acerca da história dos Grupos Escolares de Curitiba entre os anos de 1922 e 1960. Entende-se que a importância do exame histórico da imagem fotográfica fica comprometida quando o pesquisador não consegue apreender o potencial explicativo desta fonte. Assim, utilizamos o exemplo da escola primária curitibana como exercício desse olhar que procura na leitura da imagem fotográfica, aspectos que contribuam para o estudo das culturas escolares que possibilitam compreender o processo de institucionalização dos Grupos Escolares em Curitiba.
\end{abstract}

Palavras-chave: Cultura Escolar; Fotografias Escolares; Memória Escolar.

\begin{abstract}
This article intends to consider some questions concerning the use of photography in historical investigations raised by exploring a study, which has made use of this type of documentation as a main source of exposition of the history of Public Schools within the City of Curitiba from 1922 to 1960. It becomes clear historical surveys of the importance of the photographic image become compromised when the researcher is unable to apprehend the explicative potential of that source. We, therefore, use the example of the Curitiba primary school to exercise this view-point that, in the reading of the photographic image, seeks out aspects that add to the study of school culture, which, in turn, allows for the understanding of the institutionalization process of the Curitiban school groups.
\end{abstract}

Keywords: School Culture. School Photographs. School Memory.

\footnotetext{
* Doutor em História (Universidade de São Paulo), professor Associado II do Programa de Pós-Graduação em Educação.da Universidade Federal do Paraná. UFPR - 80060-170 - Curitiba - Paraná, Brasil. E-mail: marcus@ufpr.br
} 
To take a photograph is to participate in another person's (or thing's) mortality, vulnerability, mutability. Precisely by slicing out this moment and freezing it, all photographs testify to time's relentless melt. (SONTAG, 1978, p.15) ${ }^{2}$

As assim chamadas investigações histórico-educativas demonstram que um número respeitável de pesquisadores tem contribuído para a difícil tarefa proposta por White (1994) à atual geração de historiadores, a saber, de expor o caráter historicamente condicionado da disciplina histórica e presidir a dissolução da reivindicação de autonomia que esta mantém com respeito às demais disciplinas. Somos testemunhas que abordagens preocupadas em compreender novas questões e dilemas que se apresentam por meio de uma perspectiva histórica dos processos escolares asseguram um proveitoso diálogo com outros campos de conhecimento, tais como a literatura, a antropologia, a semiótica, a linguística, a arquitetura, a psicologia, entre inúmeras outras de equivalente importância.

Os resultados podem ser vistos nos estudos que utilizam fontes cada vez mais inovadoras, merecedoras de destacada importância, responsáveis por apresentar atores, abordagens e problemáticas originárias de diferentes campos do conhecimento que alcançam narrativas ricas em elucidações dentro do processo de construção histórica.

No domínio investigativo da história da educação o uso de imagens fotográficas da escola tem-se ampliado, ainda que os resultados careçam, nas mais das vezes, de análise mais sistemática desses textos fotográficos. Além da ausência de metodologia mais apropriada na análise, a falta de arquivos específicos dificulta a localização e identificação dessas imagens.

Quando iniciamos esta pesquisa sobre a mensagem fotográfica tomamos como necessária, não uma definição, mas uma apreciação sobre a condição fundamental da principal fonte de nossas análises. Para além dos princípios físico-químicos que lhe deram a existência, a fotografia não era apenas uma imagem como o era a pintura, como enfaticamente, afirma Sontag (1978). Além de ser uma interpretação do real, a fotografia é um vestígio diretamente calcado sobre o real, como uma pegada. Partindo desse ponto, ficou claro que os objetivos de nossas indagações deveriam adotar procedimentos de investigação que não se circunscrevessem apenas ao levantamento e à organização do material iconográfico, mas a um exercício contínuo de análise e interpretação que procurasse entender essa forma de representação visual e o seu uso nos estudos históricos, em 
especial, no caso, na história da educação, que se refere à realidade da escola pública primária curitibana.

Ao tratar dessa escola primária referimo-nos aos Grupos Escolares, que no Brasil, segundo Bencostta (2005), foram implantados pela primeira vez no Estado de São Paulo em 1893. Este tipo de instituição prescrevia a idealização de uma organização administrativo-pedagógica que deveria estabelecer modificações profundas e precisas na didática, no currículo e na distribuição espacial de seus edifícios. Foi notória, em particular no caso paulista, a importância da experiência da Escolamodelo - que funcionava na Escola Normal - a qual orientou não somente as determinações que levaram à criação dos grupos escolares do Estado paulista, mas também, em pouco tempo, às demais que foram adotadas por todo o país, com adequações que nem sempre atingiram os resultados esperados.

Para o caso da experiência paranaense, nessa investigação, evitamos tomar os tradicionais recortes marcados pela cronologia da história política brasileira como delimitadores do recorte temporal, para facilitar a compreensão das circunstâncias histórico-educacionais pareceu-nos mais oportuno eleger três momentos distintos na duração histórica das unidades educacionais que atendiam esta etapa do ensino.

O primeiro momento (1903 a 1920) entendemos como o de implantação dos Grupos Escolares no Estado do Paraná ainda influenciados e idealizados pela experiência paulista. Foi em 1903 que aconteceu a inauguração daquele que seria o edifício que abrigaria, ainda que precariamente, o Grupo Escolar Dr. Xavier da Silva, o primeiro do Estado. O segundo momento (1921-1949), o caracterizamos pela expansão, já que neste período alcançou-se o número de 105 unidades distribuídas por todo o Paraná. E, finalmente, o terceiro momento (1950-1971) que se sobressaiu pelo paradoxo da consolidação e extinção dos Grupos Escolares, pois a Lei de Diretrizes e Bases da Educação Nacional de n. ${ }^{0} 5.692$ de 11 de agosto de 1971 substituiu a organização de ensino primário dos Grupos Escolares, adotado desde o início da República, pelo modelo de Ensino de $1 .^{\circ}$ Grau (BRASIL, 1971).

Entendemos os três momentos acima referenciados como possuidores de temporalidades múltiplas, desvinculadas de tempos pautados pela cronologia linear e factual, que rejeita o acontecimento puro e simples como instrumento de uma análise mecanicista da causalidade 
histórica (VOVELLE, 1986). Tais circunstâncias, compreendidas as suas especificidades, contêm em si tempos de curta duração imbuídas de relações de continuidades e descontinuidades, de permanências e rupturas, que acontecem sucessivamente na média duração, sem que as transições de um momento a outro sigam modelos ou leis gerais (ARIÈS, 1986).

Este artigo testemunha que o uso de imagens fotográficas do universo escolar como fonte de pesquisa nas investigações sobre a história das instituições educacionais possui potencial analítico suficiente para colaborar na busca e organização de compreensões e explicações acerca da cultura escolar manifestada nos ambientes em que ela interage. Porém, infelizmente ainda é bastante comum encontrarmos em teses, dissertações e livros, em especial os didáticos de história, um uso ainda circunscrito à mera função ilustrativa, como se essas imagens fotográficas fossem despossuídas de um sentido e, portanto, de um discurso próprio, capaz de dialogar e propor à pesquisa a construção e a reformulação de novas problematizações ao debate histórico.

Lembramos que já foi sugerido, e Burke (1992) ressaltou mais uma vez, que quando os historiadores apresentassem novas questões à realidade do passado com a intenção de escolher novos tipos de fontes para preencher as lacunas dos documentos oficiais, alguns se voltariam para a história oral, outros à evidência das imagens. Entretanto, apesar de importantes passos terem sido dados rumo à crítica das imagens fotográficas, muito ainda tem de ser construído pelos pesquisadores que utilizam com afinco esse tipo de fonte. Somente o rever os métodos de análise, utilizar outros tipos de fontes, reexaminar questões, construir novas certezas e reconsiderar outras poderá levar a história a refletir e indagar a realidade passada, afinal, como disse Bloch (1997), um dos grandes historiadores do século XX, a história está em constante movimento.

Como neste estudo estão sendo consideradas como fotografias escolares somente aquelas produzidas no ou referidas ao universo escolar, entre os diversos tipos de conteúdos temáticos retratados destacamos aqui as fotos de classe, as de arquitetura escolar, os retratos de professores e os registros fotográficos de comemorações escolares.

Em certo sentido, podemos afirmar que tais registros são objetos culturais que guardam fortes vínculos entre a memória dos personagens da escola e a memória da própria instituição, visto que enquanto documentos, essas fotografias se consistem em testemunho e representação da escola primária em determinada época, pois revelam a um só tempo o modo de ser, mas também o de se conceber a escola; além de revelar formas determinadas de os sujeitos se comportarem e representarem seus papéis - professor, aluno, classe etc. Elas trazem informações sobre a cultura 
Memória e Cultura Escolar: a imagem fotográfica no estudo

da escola primária de Curitiba

material escolar, como os arranjos espaciais (arquitetura), as relações sociais, os contextos humanos (professores, alunos, diretores e suas respectivas posturas) e sobre as práticas escolares (festas de encerramento do ano letivo, entrega de diplomas, desfiles e comemorações cívicas, solenidades, etc.).

Neste ponto, tornam-se interessantes as considerações de Barros (1992), entre outros, ao se referir à utilização da fotografia na pesquisa histórica que tem como tema a educação. Este autor defende três aspectos fundamentais na discussão do papel da imagem fotográfica no espaço da história: a) de que essa imagem é sempre monumento de uma memória que é produzida por uma subjetividade que lhe dá a veste de real e que, para ser trabalhada como documento necessita de metodologia que a veja como linguagem, com a especificidade de um discurso; b) de que a imagem é sempre produzida socialmente, articulando sua dimensão físico-química (hoje também digital) com a produção de ideias e valores estéticos e éticos; c) de que a imagem fotográfica tem um fértil campo de análise a partir de uma metodologia qualitativa/quantitativa que vem unindo a construção de séries, de eixos temáticos, de signos que se reiteram, com o uso da semiótica e de novas tecnologias de suporte, especialmente a informática, indicando um novo potencial analítico, mas também novos riscos empiricistas.

Como suporte material da memória e testemunho da informação histórica, a imagem fotográfica se apresenta como representação de realidades imediatas. Sua técnica, afirma Walter Benjamin, por mais exata que venha a ser, pode levar o

[...] observador a sentir a necessidade irresistível de procurar nessa imagem a pequena centelha do acaso, do aqui e agora, com a qual a realidade chamuscou a imagem, de procurar o lugar imperceptível em que o futuro se aninha ainda hoje em minutos, há muito extintos, e com tanta eloquência que podemos descobri-lo, olhando para trás (BENJAMIN, 1985 p.94).

Podemos pensar, juntamente com Lavaud (1999), que é possível aproximar a fotografia de outras formas de arte representativa, de sublinhar a dimensão subjetiva de sua imagem que passa pelo enquadramento, pelo ajuste dos contrastes, pela escolha da película; entretanto todos estes pontos são secundários se comparados ao que se constitui como núcleo eidético da imagem fotográfica.

Kossoy (1999) tem defendido e utilizado, já há algum tempo, as noções de primeira realidade e segunda realidade em seus estudos sobre a compreensão interna da imagem fotográfica, 
designada por ele como documento/representação fotográfico. Para esse estudioso, a primeira realidade é o instante de curtíssima duração no qual se dá o ato do registro por meio da ação e técnica utilizada pelo fotógrafo que resultará na gravação da aparência do assunto sobre um suporte físico resultando na fotografia propriamente dita. A segunda realidade diz respeito ao assunto representado na imagem fotográfica, o evento visual da aparência do assunto selecionado no espaço e no tempo (no momento da sua primeira realidade) de um passado que não se pode mais atingir.

Com o uso desta fonte verificamos um modo específico de ver quando percebemos, nos diversos registros fotográficos, que estes foram tomados a partir da subtração de outros pontos de vista, no modo de ver do fotógrafo - que refletiu na escolha do tema e na tomada que fez para tratar esse mesmo tema. Embora as imagens que serão aqui interpretadas corporizem um modo de ver, entendemos que a sua percepção e apreciação dependam também do modo de ver próprio de cada um. Portanto, o conceito de imagem que adotamos pretende registrar comportamentos, tradições e eventos tal como o fotógrafo os percebeu. Contudo, não seria possível falar em imagem sem falar do olhar, uma vez que ao se falar em fotografia escolar envolvemos também o cotidiano escolar nas mais diversas formas e conceitos.

Assim sendo, apesar de as fotografias escolares serem uma fonte histórica carregada de sentido, a compreensão de sua representação somente será possível caso as informações resultantes da sua análise estiverem relacionadas ao contexto histórico no qual foram produzidas. Ao entendêlas desse modo, qualquer que fosse o sentido que utilizassemos, tinhamos a clareza de que o que estava ali registrado dependia da produção de um sujeito. Nas palavras de Joly (1996), embora a imagem nem sempre remeta ao visível, ela toma alguns traços emprestados do visual e passa por alguém que a produz ou reconhece.

Após estas primeiras anotações, convidamos o leitor a observar a Figura 1, perceba que se trata do momento (primeira realidade) ocorrido em um dia do ano de 1922 na cidade Curitiba, quando alunos e professores aprumaram-se elegantemente nas escadarias do edifício que abrigou o antigo Grupo Escolar Oliveira Bello para compor este registro. 


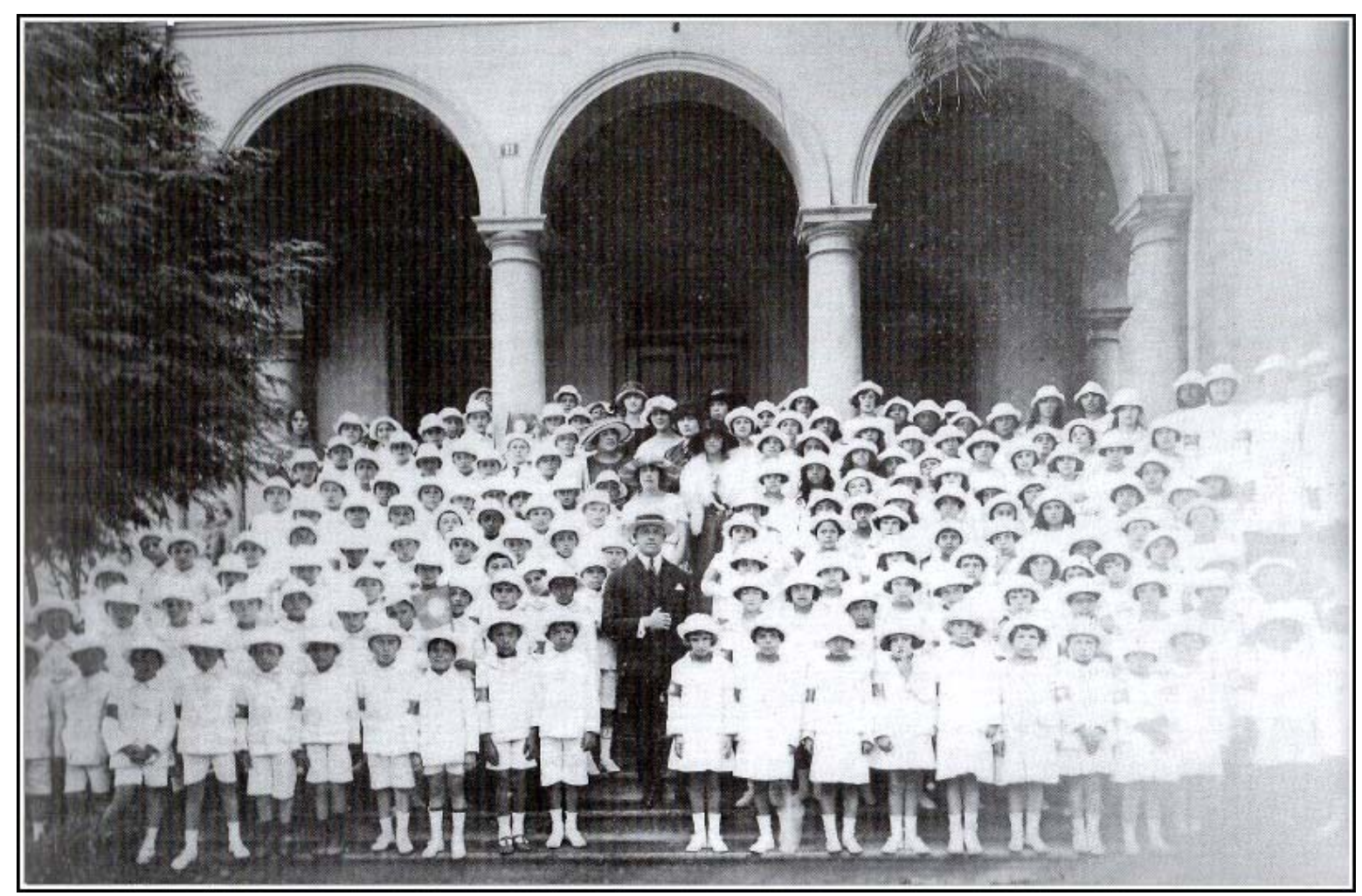

Figura 1 - Alunos e corpo docente do Grupo Escolar Oliveira Bello (1922) Fontes: Coleção Lysimaco Ferreira da Costa Acervo: Casa da Memória de Curitiba

O evento representado naquele dia ilustra aquilo que Souza (2001) entende como expressão da ordem escolar (e é nesse momento que na tipologia de Kossoy se dá a segunda realidade). Para além da solução de enquadramento, iluminação e contraste, disposição dos alunos (meninos do lado esquerdo e meninas do lado direito, separados pelo corpo docente que delimita a fronteira entre os sexos), esta fotografia de classe configura um conteúdo explícito que identifica a organização da estrutura hierárquica em que eram estabelecidas as relações de subordinação e graus sucessivos de poderes, de situação e de responsabilidades peculiar ao universo escolar público do início do século XX. Não é por um acaso que o diretor é o homem adulto em primeiro plano que se sobrepõe à imagem das colegas professoras.

Se por um lado, ao propor que entre o momento de registro do evento passado à nossa percepção atual há uma continuidade, uma escala ininterrupta da realidade que passa pelos fótons recebidos pela máquina que fez incidir essa luz na película para assim fixar a imagem, por outro, nesta mesma imagem fotográfica (que tem a inclinação de se submeter às modificações posteriores que tenderão a aprofundar a distância com o real), a autenticidade de sua estrutura fotográfica é anti-idealista, pois nela o real se dá sem ser retido e impregna o olhar com a sua presença. 
As professoras que circundam seu sublime diretor no pátio interno do Grupo Escolar 19 de Dezembro constroem uma cena que sugere a análise da Figura 2, relacionando-a com o tempo. Ao isolar-se o instante, este é retirado do fluxo do tempo. Nesse caso há, como observa Barthes (1984), certa violência na imagem fotográfica, cuja imobilização brusca torna-se temporal. Exibindo o evento, ela o isola, o corta de sua história. Somente o tecido da consciência e o trabalho da lembrança podem restituir ao acontecimento sua história. Embora esta imagem fotográfica seja a representação da lembrança, não há nela a retenção, a espessura do passado, mas apenas um corte transversal no fluxo dos eventos, que confronta o olhar com a acuidade daquele instante.

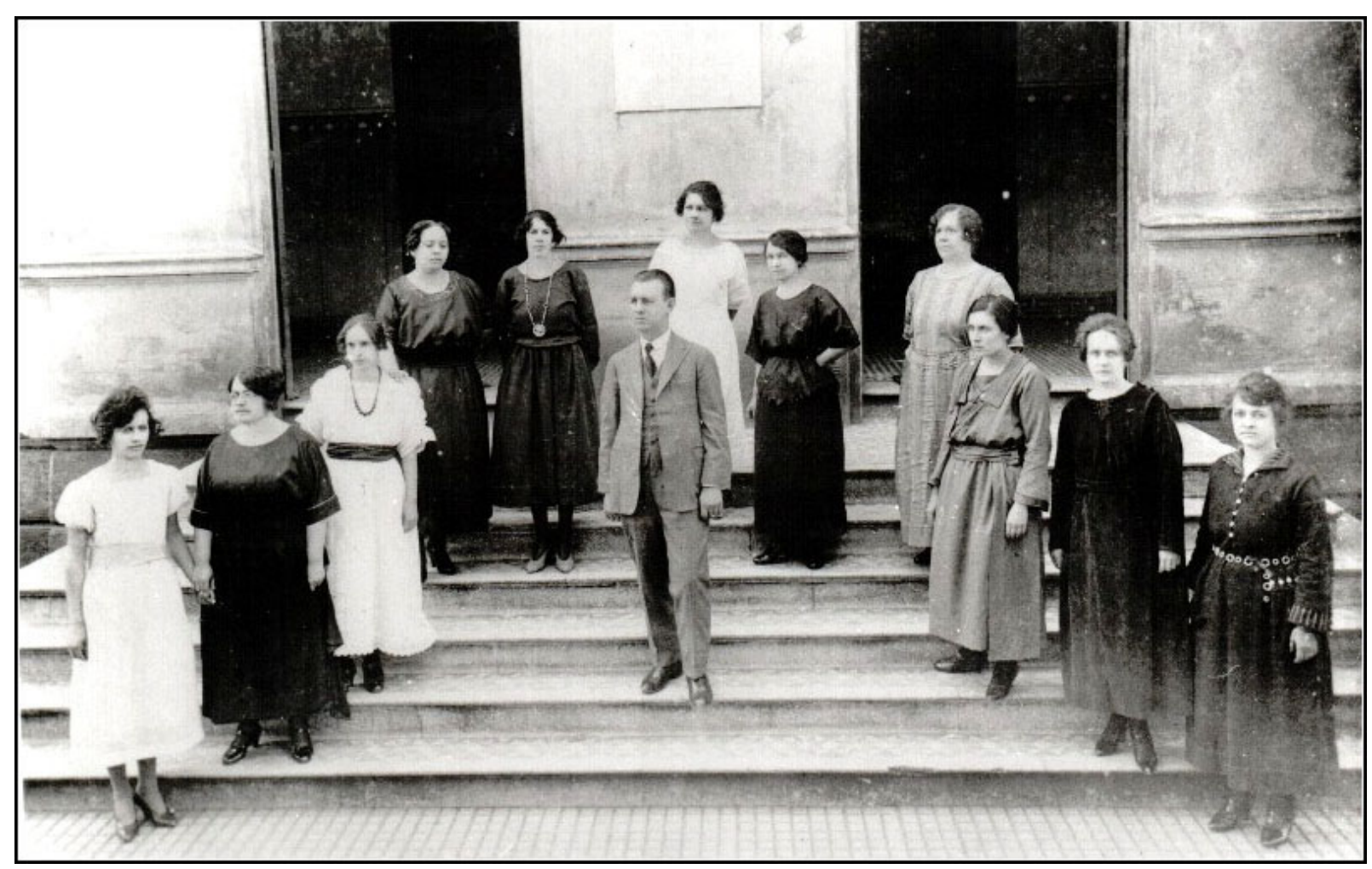

Figura 2 - Corpo docente do Grupo 19 de Dezembro (1922)

Fontes: Coleção Lysimaco Ferreira da Costa

Acervo: Casa da Memória de Curitiba

Entendemos que a leitura da imagem fotográfica não deva ser um simples exercício sobre o registro de informações, mas uma iniciativa permanente do pesquisador, que distingue, identifica e analisa aquilo que vê (GARNIER, 1983). Contudo, para que o nosso argumento que defende ser este tipo de imagem uma fonte possuidora de sentido, consideramos como essencial a compreensão das tramas e realidades no ambiente histórico em que foi gerada. Sem isso, fica comprometida a identificação de suas evidências, principalmente aquelas relacionadas às circunstâncias de sua aceitação e finalidade - importantes para concatenar as representações de um tipo de cultura escolar 
urbana com o ambiente onde a imagem fotográfica foi engendrada. Ignorar essa realidade história em que foram construídas impossibilita saber a que se referem.

Podemos perceber nas fotografias dos desfiles patrióticos o envolvimento e o entusiasmo que o universo escolar manteve com as práticas cívicas em determinados momentos da história nacional (BENCOSTTA, 2006). Para ilustrar, um exemplo possível é a Figura 3. Trata-se do desfile de 7 de setembro de 1945.

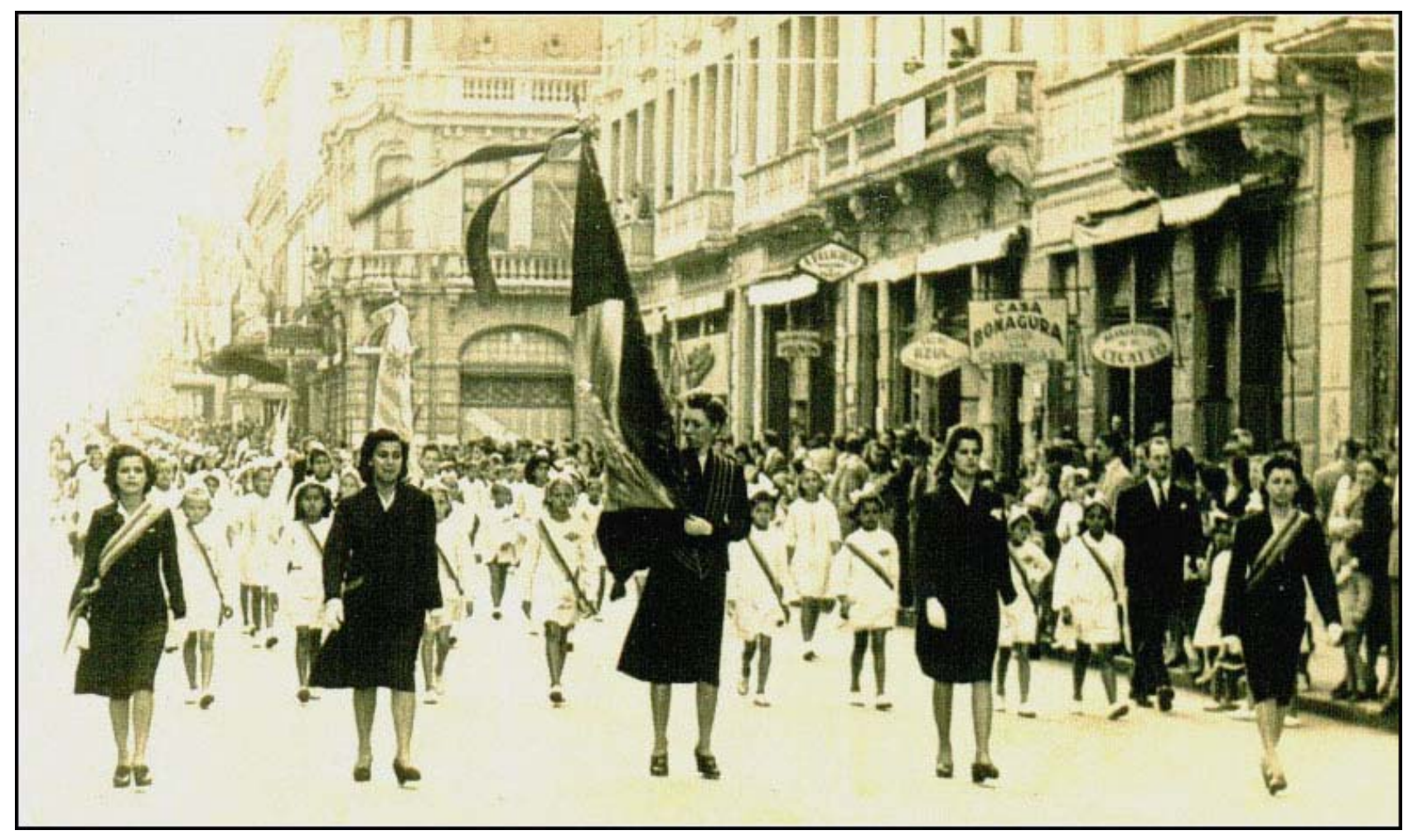

Figura 3 - Desfile de 7 de Setembro

Fonte: Grupo Escolar Republica do Uruguai (1945)

Acervo: Colégio Estadual República do Uruguai

As professoras, em trajes próprios para ocasiões solenes, que conduzem com maestria seus alunos pela Rua XV de Novembro, palco central do comércio e da política da cidade de Curitiba, atraem os olhares e os aplausos daqueles que anunciam e reconhecem neste ato uma manifestação de prestígio, dedicação, fidelidade e devoção da instituição escolar pública à pátria.

Lembramos, nesse momento, que quando foi questionado por Paul-Louis Roubert sobre as possíveis respostas que o historiador da fotografia podia trazer à história, Jean-Luc Moulène (ROUBERT, 2001) afirmou que as condições de produção e de difusão contribuem na construção da imagem e mesmo na constituição do documento histórico. Ao organizar o corpus, identificar os diferentes tipos de imagens, o historiador fornece os instrumentos críticos necessários à análise, 
mas, talvez antes disso seu papel consista, ainda hoje, em demonstrar a importância da imagem fotográfica como material de estudo histórico.

Assim, se liberadas de seu compromisso de registro, do vínculo com a realidade histórica localizada no tempo passado, as fotografias podem apenas aspirar à instauração de outras situações, outros significantes que não interessariam diretamente aos estudos históricos. Mas ao contrário, ela é capaz de permitir narrar novas histórias, construir outras identidades, outros passados, dar-se talvez uma imagem, fundar uma memória. Uma rearticulação de passado, presente e futuro que mostra como a fotografia pode levar a pensar a história (PEIXOTO, 1998).

Ao partirmos do princípio que a fotografia possui um sentido que lhe é peculiar, nos moldes pensados por Aumont (1993), quando salientou que não há imagem pura, e como toda representação é relacionada por espectadores históricos aos sucessivos discursos ideológicos, culturais e simbólicos, afirmamos como o fez anteriormente Armando Barros, ser a imagem fotográfica um documento que necessita da análise crítica enquanto monumento. E o fazemos para destacar a relação da fotografia com a memória, seja individual ou coletiva.

A este propósito, Jacques Le Goff ressalta a relevância da fotografia para o desenvolvimento da memória coletiva à medida que contribuiu para a multiplicação e democratização dessa memória dando-lhe "[...] uma precisão e uma verdade visuais nunca antes atingidas, permitindo assim guardar a memória do tempo e da evolução cronológica” (LE GOFF, 2003: 460). É nesta interseção entre história e memória que podemos considerá-la como monumento/documento ${ }^{3}$ nos termos indicados por esse historiador, quais sejam como resquícios, testemunhos do passado e fonte de informação para a pesquisa histórica.

A imagem compreende, portanto, um suporte material da memória. Esta formulação teórica leva-nos a concluir que todo documento é monumento na medida do resultado do esforço das sociedades em quererem impor ao futuro (voluntária ou involuntariamente) imagens de si próprias, uma vez que um dos atributos do historiador é desmontar e desestruturar esta produção dos documentos monumentos.

Utilizamos essa discussão para finalizar nossos comentários com o estudo da Figura 4, a qual apresenta uma imagem distinta da rigorosa representabilidade da Figura 1. A singeleza da professora e seus treze alunos fazem brilhar os pequenos rostos à espera do momento do registro. A magnificência da entrada principal da escola é substituída por um pequeno lance da calçada defronte a uma das salas de aula voltada para o pátio interno do Grupo Dr. Escolar Xavier da Silva.

A rigidez da mira matemática do fotógrafo ao enquadrar seus personagens não impediu a descontração de alguns deles, mesmo que fosse para encenar certo ar introspectivo como no olhar da menina na extrema esquerda da primeira fileira, ou então, um sorriso desfranzido como o do 
garoto no primeiro plano. Naquele momento, a bela professora e seus pequenos alunos indicam um instante em que a maleabilidade ocupa o antigo espaço da circunspecção, tão comum nas fotografias escolares do início do século XX. Não teria sido por simples questão de disposição dos personagens que as filas de meninos estão divididas com linhas de alunas, e muito menos a jovem professora ter cedido sua posição no primeiro nível para a aluna, mas senão fragmentos de uma cultura escolar que demonstra traços de mudança na expressão de sua ordem escolar.

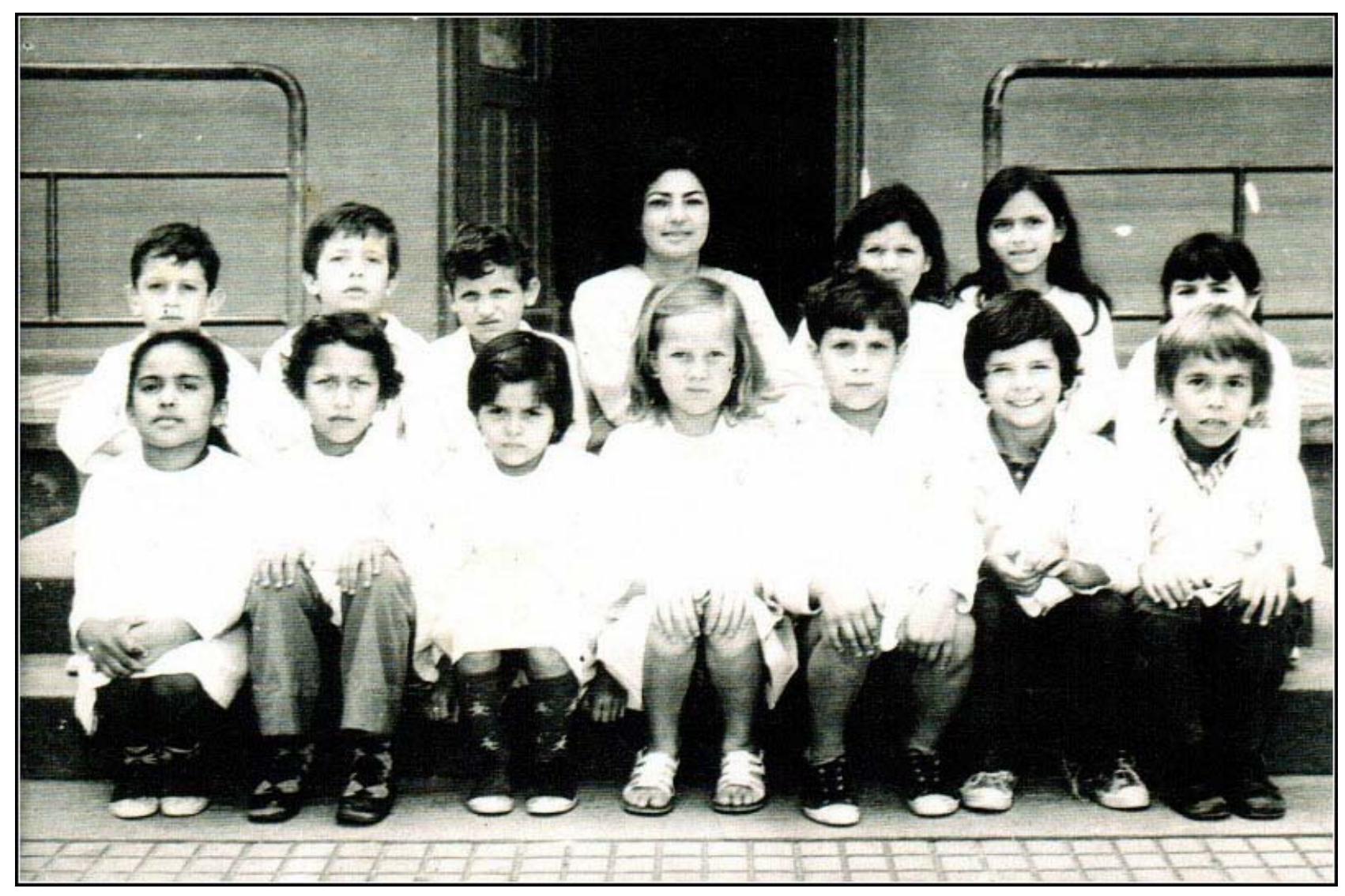

Figura 4 - Foto de Classe do Grupo Escolar Dr. Xavier da Silva (década de 1960) Acervo do Colégio Estadual Dr. Xavier da Silva

\section{Concluindo ...}

No caso da fotografia escolar o que verificamos neste artigo é um conceito de mensagem que pretende registrar comportamentos, tradições, eventos tal como o fotógrafo os percebeu. Por possuir um caráter relativo que perpassa a sua própria iconicidade, a fotografia não remete somente a um objeto possivelmente real, mas também a um objeto necessariamente real, uma emanação do referente e testemunha de um “aconteceu assim”. 
Não seria, portanto, a expressão fotográfica um mero reflexo, nem a reprodução fiel da realidade, mas uma mediação (vermittelung) no sentido adotado por Hegel, ao discutir a ideia de dialética, inserida em um contexto de experiência que dialoga com a memória. Ao pensarmos na ontologia da imagem fotográfica, podemos afirmar que essa fonte sempre possuirá um estatuto de evidência, mesmo que, teoricamente, existam concepções miméticas tradicionalistas que aceitem a fotografia como uma simples impressão (impressio) ou espelho (speculum) da realidade, ela é muito mais uma construção imaginária erigida histórica e socialmente, que não deixa de ser metaforizada e idealizada.

Segundo Gombrich (1982), esta significação é, em grande parte, resultado da experiência e do saber que o indivíduo que a contempla adquiriu anteriormente. Neste sentido, a imagem não é uma simples representação da realidade, mas um sistema simbólico. Esse falso realismo atribuído à imagem fotográfica é resultado de uma leitura que somente atenta para a aparência visual das formas sensíveis, excluindo as demais faces que a modelam. Além disso, a suposta universalização da relação entre a fotografia e a realidade é questionável se considerarmos que dados de outros universos culturais indicam a possibilidade de não reconhecimento da imagem fotográfica como análise do real.

Podemos fazer uma distinção entre o olho e o olhar, na qual ao olhar consiste estar voltado para conhecer, já que se aceita a noção de ponto de vista como sendo ideias e opiniões que dependem do lugar de onde se vê o real, já o olho é o órgão que proporciona esse contato. Olhar é uma ação que significa dirigir a mente para um ato de in-tencionalidade, um ato de significação (BOSI, 1988, p.64).

Partindo do conceito de que olhar é conhecer, é informar-se, podemos atribuir à fotografia o conhecimento por meio do olhar, não apenas pela sua natureza técnica, mas porque o olhar que vai além do processo ótico. A fotografia informa, porque permite, sobre certos aspectos, conhecer.

Representar o mundo escolar por meio de imagens materiais está associado à maneira que o homem encontrou para entender e se apropriar do mundo a sua volta. No caso da fotografia escolar, a representação do mundo possibilita o conhecimento do e a informação sobre mesmo.

Dessa forma, a imagem fotográfica apresenta-se como um testemunho visual e como representação que requer, pois, uma leitura específica. Como fonte de informação, recordação e até emoção, a imagem fotográfica associa-se à memória e introduz uma nova dimensão no conhecimento histórico. O desafio para o historiador que busca utilizar a fotografia como objeto de estudo reside justamente na interpretação. Enquanto receptor da imagem, ele não pode desconsiderar os mecanismos implicados em sua recepção. 
Memória e Cultura Escolar: a imagem fotográfica no estudo

da escola primária de Curitiba

Na memória das escolas públicas, as fotografias inscrevem-se na imanência do tempo presente, nos acontecimentos significativos para professores, alunos e funcionários, partícipes dessa temporalidade do agora, e assim, elas se constituem em um instrumento de memória institucional e de recordação. Neste artigo procuramos demonstrar que a potencialidade significativa das fotografias é portadora de elementos para a compreensão das culturas escolares manifestadas no universo educacional.

\section{Notas}

\footnotetext{
1 Este artigo é resultado das análises do projeto de pesquisa $A$ imagem fotográfica no estudo das instituições educacionais: os grupos escolares de Curitiba (1903-1971), financiado pelo CNPq com bolsa produtividade de pesquisa. Pesquisador do CNPq e coordenador do Núcleo de Estudos e Pesquisas em História da Arquitetura Escolar (NEPHArqE).

${ }^{2}$ Tomar uma fotografia é compartilhar da mortalidade, vulnerabilidade e mutabilidade de outra pessoa (ou objeto). Exatamente por lapidar e congelar determinado momento, toda fotografia é uma testemunha da implacável dissolução do tempo. (Tradução livre)

${ }^{3}$ Segundo Jacques Le Goff, a diferença entre um documento e um monumento é sua escolha temporal como algo passível de ser lembrado. Por um lado, os monumentos são "heranças do passado (...) tudo aquilo que pode evocar o passado, perpetuar a recordação, por exemplo, os atos escritos”; e por outro documento “[...] será o fundamento do fato histórico, ainda que resulte da escolha, de uma decisão do historiador, parece apresentar-se por si mesmo como uma prova histórica” (LE GOFF, 2003, p. 526).
}

\section{Referências}

ARIÈS, P. Uma nova educação do olhar. In: DUBY, G., ARIÈS, P., LE GOFF, J., LA DURIE, E. R. História e nova história. (Trad. Carlos da Veiga Ferreira). Lisboa: Teorema, 1986, p. 21-31.

AUMONT, J. A imagem. (Trad. Estela dos Santos Abreu e Cláudio Cesar Santoro). Campinas: Papirus, 1993, p. 317

BARROS, A. M. O tempo da fotografia no espaço da história: poesia, monumento ou documento? In: NUNES, C. (Org.) O Passado sempre presente. São Paulo: Cortez, 1992, p. 69-84.

BARTHES, R. A câmara clara: nota sobre a fotografia. (Trad. Júlio Castañon Guimarães). Rio de Janeiro: Nova Fronteira, 1984, p. 185

BENCOSTTA, M. L. Grupos Escolares no Brasil: um novo modelo de escola primária. In: STEPHANOU, M. \& BASTOS, M. H. C. (Orgs.). Histórias e Memórias da Educação no Brasil. Vol. III - Século XX. Petrópolis: Vozes, 2005, p. 68-76

. Desfiles patrióticos: Memória e cultura cívica dos grupos escolares de Curitiba (19031971). In: VIDAL, D. (Org.). Grupos Escolares: cultura escolar primária e escolarização da infância no Brasil (1893-1971). Campinas: Mercado de Letras, 2006, p. 299-321.

BENJAMIN, W. Pequena história da fotografia. In: Obras Escolhidas, v. I. (Trad. Sérgio Paulo Rouanet). São Paulo: Brasiliense, 1985, p. 91-107. 
BLOCH, M. Introdução à História. Edição revista, aumentada e criticada por Étienne Bloch. Lisboa: Publicações Europa-América, 1997, p. 289

BOSI, A. Fenomenologia do olhar. In: NOVAES, A. (Org.). O olhar. $3^{\text {a }}$ ed. São Paulo: Companhia das Letras, 1988, p. 64-87

BRASIL. Lei de Diretrizes e Bases da Educação Nacional Lei n. 5.692, de 11 de agosto de 1971. Fixa as diretrizes e bases para o ensino de $1^{\circ}$ e $2^{\circ}$ graus, e dá outras providências.

BURKE, P. A Escrita da História. Novas Perspectivas. (Trad. Madga Lopes). São Paulo: Editora da Unesp, 1992, p. 354

GARNIER, F. Thesaurus Iconographique: systéme descriptif des representation. Paris: Le Leopard d'Or, 1983, p. 240

GOMBRICH, E. The Image and the Eye: Further Studies in the Psychology of Pictorial Representation. Oxford: Phaidon, 1982, p. 320

JOLY, M. Introdução à Análise da Imagem. (Trad. Marina Appenzeller). Campinas: Papirus, 1996, p. 152

KOSSOY, B. Realidades e ficções na trama fotográfica. São Paulo: Ateliê Editorial, 1999. p.149

LAVAUD, L. L’Image. Paris: Flammarion, 1999, p. 247

LE GOFF, J. História e Memória. 5.a ed. Campinas: Editora da Unicamp, 2003, p.541

PEIXOTO, N. B. Paisagens Urbanas. São Paulo: Senac, 1998, p. 347

ROUBERT, P-L. Entretien avec Jean-Luc Moulène. Le Bulletin. Société Française de Photographie, Paris, n.10, $147^{\mathrm{e}}$ année, s/p, 2001.

SONTAG, S. On Photography. New York: Farrar, Straus and Giroux. 1978, p. 207

SOUZA, R. F. Fotografias escolares: a leitura de imagens na história da escola primária. Educar em Revista. n.18, 2001. p. 75-101

VOVELLE, M. A história e a longa duração. In: LE GOFF, J. A História Nova. Rio de Janeiro, Martins Fontes, 1986, p.68-97.

WHITE, H. Trópicos do Discurso. Ensaios sobre a crítica da cultura. (Trad. Alípio Correia de Franca Neto). São Paulo: Edusp, 1994, p.310.

\section{Fontes Iconográficas}

Figura 1 - Alunos e corpo docente do Grupo Escolar Oliveira Bello (1922)

Casa da Memória de Curitiba - Coleção Lysimaco Ferreira da Costa

Figura 2 - Corpo docente do Grupo 19 de Dezembro (1922) 
Memória e Cultura Escolar: a imagem fotográfica no estudo

da escola primária de Curitiba

Casa da Memória de Curitiba - Coleção Lysimaco Ferreira da Costa

Figura 3 - Desfile de 7 de Setembro - Grupo Escolar Republica do Uruguai (1945)

Acervo do Colégio Estadual República do Uruguai

Figura 4 - Foto de Classe do Grupo Escolar Dr. Xavier da Silva (década de 1960)

Acervo do Colégio Estadual Dr. Xavier da Silva

Recebido em: 02/08/2010

Aprovado em: 09/02/2011 